\title{
OPERATIONS OF THE UKRAINIAN ENERGY MARKET IN TERMS OF ACCESSING FOREIGN MARKETS - WAYS OF IMPROVEMENT
}

\author{
Dmytro Tkach ${ }^{1}$ \\ ${ }^{I}$ Postgraduate student, «KROK» University, Kyiv, Ukraine, e-mail: tkach_k@ukr.net, ORCID: https://orcid.org/0000- \\ 0009-1856-5523
}

Citation:

Tkach, D. (2020). Operations of the ukrainian energy market in terms of accessing foreign markets - ways of improvement. Economics, Finance and Management Review, (2), 35-42. https://doi.org/10.36690/2674-52082020-2-35

Received: April 25, 2020

Approved: May 18, 2020

Published: June 05, 2020

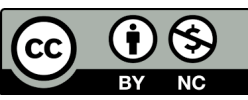

This article is an open access article distributed under the terms and conditions of the Creative Commons Attribution (CC BY-NC 4.0) license

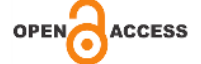

\begin{abstract}
Socio-economic stability of any society, quality assurance and improvement of life of its population largely depend on the reliability and efficiency of the country's energy market. Ukraine's energy sector has sufficient electricity and a well-developed network to supply electricity to consumers, but the current significant problems are due to outdated technologies, depreciation of fixed assets, imperfect management, non-transparent legal framework and others leading to a crisis. Thus, the urgent issue of reforming the energy market of Ukraine in order to create a full and competitive environment, incentives for investment, improvement of financial and economic indicators is particularly relevant. An important aspect in this regard is also to determine the prospects of the Ukrainian energy market. The purpose of the article is to develop ways to improve the operations of the Ukrainian energy market in terms of entering foreign markets. The author used the methods of static and logical comparison, systematization and generalization, which made it possible to achieve the goal of the study. To achieve the goal set in the article, ways to improve the activities of the energy market of Ukraine in terms of access to foreign markets were developed. The article studies and systematizes the basic requirements for the production, transportation and consumption of products of the energy market of Ukraine in accordance with international standards.
\end{abstract}

Keywords: small business, region, socio-economic development, entrepreneurship, sustainable development, state support.

JEL classification: F47, L94, P18

Formulas: 0; fig.: 0; tabl.: 0; bibl.: 11

Introduction. Socio-economic stability of any society, quality assurance and improvement of life of its population largely depend on the reliability and efficiency of the country's energy market. Ukraine's energy sector has sufficient electricity and a well-developed network to supply electricity to consumers, but the current significant problems are due to outdated technologies, depreciation of fixed assets, imperfect management, non-transparent legal framework and others leading to a crisis. Thus, the urgent issue of reforming the energy market of Ukraine in order to create a full and competitive environment, incentives for investment, improvement of financial and economic indicators is particularly relevant. An important aspect in this regard is also to determine the prospects of the Ukrainian energy market.

Literature review. The scientific works of Zerkalov D., Kuznetsova I., Kuznetsova I., Gitelman L., Papkova B., O. Sukhodoliya, V. Tochilin, A. are devoted to the study of the functioning of energy systems, the reasons for their formation, technological features of electricity as a commodity that determine the features of energy companies. Tukenov, V. Fortov, I. Franchuk, V. Tsaplin and others. However, at the present stage of development of the electricity sector in Ukraine as a whole and its individual enterprises in times of profound structural changes, in our opinion, this requires in-depth study.

Aims. The purpose of the article is to develop ways to improve the operations of the Ukrainian energy market in terms of entering foreign markets. 
Methods. The author used the methods of static and logical comparison, systematization and generalization, which made it possible to achieve the goal of the study.

Results. "According to the Ministry of Energy and Coal Mining of Ukraine data, Ukraine managed to increase its power exports by $46.5 \%$, reaching 3.4 billion $\mathrm{kW} \mathrm{h}$, in the first six months of 2019 as compared against the equivalent period in 2018. The issues with procuring anthracite for coal-based power generation operations did not prevent Ukraine from building up its electric power exports. Based on expert estimates, the world will reach the peak electric power output based on coal consumption in 2026. The coal demand in 2040 will be $-15 \%$ against 2018 figures. The major destinations for Ukrainian power export in 2019 included Hungary (52.9\% of all deliveries), Moldova (22\%), Poland (19.5\%), Slovakia (3.2\%) and Romania (2.4\%). According to the State Fiscal Service, the 7-month exports of electricity yielded $\$ 160$ million of proceeds for Ukrainian companies.'[1]

Ukraine has a regulatory framework in place enabling the domestic power market to access foreign markets. "The primary document regulating those activities is the Law of Ukraine "On the Electric Power Industry" as amended on March 19, 2009 by Law \#1164-vi. It is this legislature that specifies the particularities of electric power energy export in Ukraine.'[2]

Pursuant to the above legislature power suppliers purchase the required energy capacity for export in the wholesale electric power market of Ukraine. Further, to transfer the power abroad, they need to be able to use Ukraine's cross-border power grids. Export quotas are obtained through the auction process.

Auction sales are effected by Ukrenergo National Power Company, for a maximum period of 1 year, and it is this company that arranges electric power transportation via Ukrainian electric networks. Pursuant to the auction process approved by the National Energy and Utilities Regulatory Commission (NKRE), auction sales are generally held monthly, subject to the availability of relevant transfer capabilities in the cross-border electric grids of Ukraine.

Auction participants must hold a permit for electric power transmission without obligations to any specific entity, must be members of the Ukrainian wholesale power market and must not have any debts related to the electric power purchase in the wholesale market. A company offering the highest price wins the auction.

If, during two consecutive months, the winning bidder uses less than $70 \%$ during 30 days on the average of the awarded commercial capability of Ukraine's crossborder electrical networks for power transmission, the capability is returned to auction.

"Subject to the laws of Ukraine, electric power exporters must meet the following formal requirements:

1. Be a resident of Ukraine.

2. Hold a license quota for at least the annual volume of power exports.

3. Have a contract with Energorynok State Enterprise (DPE) for the procurement of required electric power capacity. 
4. Have a contract with Ukrenergo NPC allowing access to the transfer capabilities of cross-border electrical networks, after winning the public auction.

5. Have a contract with a foreign power buyer.

6. Be a registered participant (member) of the Ukrainian wholesale electric power market.

7. Not have outstanding obligations regarding electric power in Ukraine and outstanding tax liabilities in Ukraine.

8. Purchase at least $70 \%$ of the electric power nominations, with daily and monthly checks of the consumption schedule.

9. Have sufficient funds in accounts to make advance payments under the contracts with Ukrenergo NPC and DPE" [2].

"In June Ukrenergo signed the "Agreement on the Conditions for the Future Interconnection of the Power System of Ukraine and Moldova with the Power System of Continental Europe" with the European Network of Transmission System Operators for Electricity (ENTSO-E). The Agreement is to remain in force until 2025, by which time Ukraine must connect to the networks of 34 European countries complying with their standards. And the necessary changes concern not only the power system's technical specifications but the playing rules in the Ukrainian market as well. The Agreement inaugurated completion of the first phase of the project for Ukraine's accession to the European electricity system - Kyiv had submitted the relevant application back in 2005" [3]. Pursuant to that document, Kyiv undertook to align Ukrainian electric grids with the European requirements. This ambitious goal was reflected in the Energy Strategy of Ukraine for 2035 and in the Law on Electricity Market. Put to practice, this means that Ukraine must adjust the automatic frequency and capacity regulation mechanisms of its power system to conform to European rules.

To achieve this, it is necessary for the Ukrainian system to withdraw from the interconnected electricity network of Russia, Belorussia and Moldova. Concurrently, European partners will be tracking the main system parameters for about one year. It is difficult to forecast the outcomes of the checks since electric power production is not stable during 24 hours; there are periods when consumers do not collect the whole volume or, on the contrary, require more. Unfortunately, Ukraine does not have sufficient internal capacities to ensure effective balancing of the electric power; pumped storage power plants (PSPPs) could improve the situation but their number is inadequate. The construction of Dniester PSPP, one of the world's largest pumped storage hydropowers, is still in progress. Its main functions include regulation of the Ukrainian power system frequency and load patterns and creation of emergency power reserves. Obviously, combined heat and power plants (CHP) can be also used to adjust the basic electric network indicators but they are quite expensive to operate.

The next step could be building up the power line transmission capacity in Western Ukraine, due to direct current link installation on the Hungarian border. "There are currently three $750 \mathrm{~kW}$ lines, three $400 \mathrm{~kW}$ lines and three $220 \mathrm{~kW}$ lines extending to Poland, Hungary, Slovakia and Romania. 
Ukrenergo's calculations revealed that around one billion euros are required to synchronize the Ukrainian energy system with European networks" [4].

At the same time, Ukraine has been transferring electric power to Europe via "Burshtyn Island" from early 2000s. This became possible after the withdrawal from the united Ukrainian networks and synchronization with the European power system. The Island includes Burshtyn TPP, Kalush CHP and Tereblia-Rikska HPP whose combined capacity is 2500 MWth. "Over the period of January-September 2018 Ukraine increased its power exports by $47.6 \%$ (reaching 4,181 billion $\mathrm{kW} \mathrm{h}$ ) in comparison with the equivalent period in 2019.

Thus, electricity exports from Burshtyn TPP in the direction of Hungary, Slovakia and Romania grew by $19.6 \%$ (by 407.8 million $\mathrm{kW} \mathrm{h}$ ), achieving 2,488 billion $\mathrm{kW} \mathrm{h}$. Electricity sales to Poland dropped by $3.5 \%$ (by 26 million $\mathrm{kW} \mathrm{h}$ ), to the level of 723.2 million $\mathrm{kW} \mathrm{h}$. Power exports to Moldova amounted to 970 million $\mathrm{kW} h$ against 3.7 million $\mathrm{kW} \mathrm{h}$ in the nine months of 2017" [5].

"On August 3, 2017 the Consortium of international companies EDF Trading, Westinghause, Polenergia International submitted to the Ministry of Energy and Coal Industry of Ukraine the feasibility study for the Energy Bridge Ukraine - European Union project.

This is the first proposal of public-private partnership of this kind, not only in the energy sector of Ukraine but at the international state level as well. The proposed project opens up new horizons both for the energy sector and for increasing the geopolitical importance of Ukraine in Central Europe" [6].

Ukrenergo NPC, as the Ukrainian transmission system operator, made an agreement for collaboration on the synchronization project with ENTSO-E - the European transmission system operators organization which is assigned the functions of the energy market regulator according to the Third Energy Package.

So how will the above agreement affect the ways of improving the operations of the domestic power market in terms of accessing foreign markets?

Discussion. What are the events associated with the synchronization of Ukrainian and EU power systems?

One should seek the answers in the future cooperation with the consortium of companies EDF Trading, Westinghouse, Polerergia International. This international association is proposing to implement a number of investments, first of all in the upgrading and reconstruction of the $750 \mathrm{kV}$ Rzeszów-Khmelnytskyi powerline using the public-private interaction model. The investments would create potential for the export of $1000 \mathrm{MW}$ of electric power, which is generated by Energoatom at the second unit of Khmelnytskyi Nuclear Power Plant, to Europe.

The important point is that the consortium plans to stay in Ukraine for a long time, and for this reason proposes to synchronize exports from the Khmelnytskyi Nuclear Power Plant generating unit with the funding of the infrastructure of Energoatom National Nuclear Energy Generating Company of Ukraine, with a view to enhancing its power capacities which in its turn would improve the electric power generation efficiency. 
"Furthermore, the currency assets Energoatom will receive from the electricity export under the long-term contract will be used to complete the third unit construction and begin the fourth unit of Khmelnytskyi NPP. This concept was approved by Order \#671-p as of June 15, 2015 "On the Energy Bridge Ukraine European Union Pilot Project" issued by the Cabinet of Ministers of Ukraine" [7].

The appeal of the consortium's proposal is that it does not require government guarantees and does not draw on budget costs. Energoatom National Nuclear Energy Generating Company of Ukraine will get the opportunity, for the first time since its establishment, to enter foreign financial markets, creating the potential for upgrading and technological diversification, and that would provide conditions for competing adequately with companies operating in the external markets. The long-term contract for the overseas electricity transmission will secure lending assets for Energoatom from foreign banks.

The inflow of foreign capital to the Ukrainian power industry, in its turn, will promote further growth of the country's economy, creation of new jobs and development of regions where the nuclear power stations are located.

Entry of European Union private companies to the energy sector of Ukraine and planning of investment schemes involving electric power transfers as payment for the invested funds are a way to create a supportive environment that will stimulate the overall economic growth. The country's energy capacities have great potential and, provided that an environment friendly to foreign investments is assured, this economic sector could be one of the most effective ones in what concerns international business activities.

"According to market experts' estimates, the power prices in EU countries in the next 20 years will be increasing by an average of $1 \%$ annually, ranging 36-50 euro/MWh. And considering the current price for the electricity of nuclear plants in Ukraine, which is 16.3 euro/MWh, its ability to compete in the EU market is evident even in view of the investment aspect" [8].

"The $750 \mathrm{kV}$ Rzeszów-Khmelnytskyi powerline was decommissioned in 1993 when the power systems of Poland and the European Union were synchronized. This valuable asset was not used for 24 years. Restoring the operation of the $750 \mathrm{kV}$ power line, the Energy Bridge Ukraine - European Union Project is the first phase of the project aimed at synchronizing the energy systems of Ukraine and the EU" [9].

This way, Ukraine will take the first step to free itself of the Russian energy monopoly on the international scene. Unfortunately, Kyiv had failed to disengage from Russia' tight embrace in the energy sector for 26 years - since July 1, 1991 when the Warsaw Pact expired, and even today Moscow imposes its rules in this economic sector which is so important for Ukraine.

The same applies to Baltic States which are also in the IPS/UPS energy system meaning that they are directly influenced by Russia. And the same is valid for Moldova.

Therefore, the Energy Bridge Ukraine - European Union Project will enable Energoatom to access the Central and Eastern European energy markets and establish new-level collaborations with the European power system, gaining an opportunity to 
transfer electric power to the Baltics and securing a key element for the energy hub creation in the CEE.

Considering that Ukraine has excess electricity generation capacities while European countries need great amounts thereof, the expedited project implementation is an urgent task set before the Ukrainian foreign economy policy makers. It is safe to forecast that thanks to this project Poland, Slovakia, Romania and Hungary will be receiving Ukrainian electricity in the nearest future, and that is the highroad to the European market.

There are plans to sign in 2022 a long-term contract for electric power transmission via European electric grids, in order to export the power from Khmelnytskyi NPP Unit \#2.

To implement the project, the Ministry of Energy and Coal Mining of Ukraine, as the country's government representative, needs to sign an agreement with foreign private companies.

Furthermore, a long-term contract for electric power transmission from Khmelnytskyi NPP Unit \#2 should be made between Energoatom National Nuclear Energy Generating Company of Ukraine and a private company.

In view of the above, further design and construction of Khmelnytskyi NPP Units \#3 and \#4 are highly relevant. Verkhovna Rada of Ukraine needs to adopt the corresponding law to enable that.

The Government of Ukraine began cooperating with one of the UK's largest banks, Barclays, regarding a loan to complete construction of Khmelnytskyi NPP Units \#3 and \#4 in 2020-2022. What is interesting about those arrangements is that the loan will be secured against electric energy supply to Europe.

The commissioning of the fourth Khmelnytskyi NPP unit is scheduled for 2026, and this is when the Energy Bridge project will be completed.

The establishment of an energy bridge between Ukraine and the EU caught the interest of many companies operating in the power markets of Europe, Asia and USA. Consortiums are also taking an interest and are willing to participate in the construction of Khmelnytskyi NPP Units \#3 and \#4, and to provide equipment and advanced technologies. There are a fair number of companies inquiring to sell electricity to EU countries on a continuous basis.

For the Energy Bridge project implementation the " $1+2$ " definition was used, meaning in practice that the funds received from power exports in the foreign markets are used to finish the construction of two new power generating units.

In a situation when Ukraine shows a tendency towards electric power use reduction, entry to foreign markets is an extremely important task for the Ukrainian energy sector.

The following figures confirm the above. Ukraine's power balance for 2019 included plans to decrease the power generation by nuclear power stations to 82 million $\mathrm{kWh}$ which is 6 million $\mathrm{kWh}$ less than in 2015. In 2018, in the winter period when the electricity consumption rises significantly, Ukrainian nuclear power stations operated with balance limitations reaching almost $1.7 \mathrm{GW}$. 
This project is also appealing because it does not involve great expenses to ensure the exports from Khmelnytskyi NPP's second unit, while the funds gained will enable the commissioning of the third and fourth units of the plant. Speaking of which, the $3^{\text {rd }}$ power generating unit is completed $73 \%$ and the $4^{\text {th }}-28 \%$.

There is an ongoing active search for investors and equipment suppliers to finish the construction. Korea Hydro \& Nuclear Power and China National Nuclear Corporation are greatly interested in the project and willing to participate in the generating units erection: APR-1400 (Korea) and HPR-1000 (China). In addition, there is a proposal for the WWER reactor by Skoda.

"Representatives of China National Nuclear Corporation recently announced their proposals in Kyiv, at the headquarters of Energoatom. They came to offer their participation in the completion of \#3 and \#4 units at Khmelnytskyi NPP using the socalled " $1+1$ " formula, i.e. the third unit would be built in keeping with the WWER technology, and the fourth would be completed with the Chinese technology. Hualong would be the reactor type used." The Chinese company representatives also talked about the potentially high level of Ukrainian localization involved in the unit construction and about the company's readiness to provide $85 \%$ funding of the project cost."'[10]

"Significant company events in terms of Ukraine's energy sector access to the international markets and evidence of the positive power industry trends include the following:

- resumption of the operations of the United Energy System (UES) of Ukraine concurrently with the UES of Russia (2001);

- commencement of operations at Burshtyn Island TPP concurrently with the European energy association (currently ENTSO-E) (2002);

- to enable full integration of Ukraine's UES into the European power systems, an application was submitted to the ENTSO-E Commission for inclusion of Ukraine's and Moldova's energy systems to ENTSO-E as a single control block (2006), and measures to prepare for the energy systems integration were designed and are being implemented (starting 2008);

- large-scale cooperation with global financial organizations (starting 2005) to secure investments for the most resource-intensive and long-term projects for the upgrading and capital development of the company's energy facilities.

There is no doubt that apart from the equipment upgrading which is essential for the electric power quality, transmission reliability and environmental safety, the following steps also evidence that the company's vector is towards bringing the electricity quality parameters in line with the European standards:

- creation of an automated electric power metering system for the Ukrainian UES facilities based on Ukrenergo NPC resources;

- receipt of the international certificate on the conformity of the operational and engineering management of Ukraine's UES and of the electric power transmission via mains systems and cross-border electricity networks to the international standard ISO9001:2008" [11]. 
Conclusion. To achieve the goal set in the article, ways to improve the activities of the energy market of Ukraine in terms of access to foreign markets were developed. The article studies and systematizes the basic requirements for the production, transportation and consumption of products of the energy market of Ukraine in accordance with international standards.

\section{References:}

1. Export of electricity in Ukraine (2019), retrieved from: http://www.ukrenergoexport.com/ru/ElectricityExport.

2. The Verkhovna Rada of Ukraine (2009), The Law of Ukraine "On the amendments to the Law of Ukraine "On the Electric Power Industry", retrieved from: https://zakon.rada.gov.ua/laws/show/1164-17\#Text.

3. Energy Reforms: An Overview (2019), retrieved from: https://issuu.com/uaenergy/docs/monthly_march_final_rs.

4. Cabinet of Ministers of Ukraine puts forward a proposal for Verkhovna Rada to denounce the agreement with Russia for the construction of two generating units at KhNPP (2015), retrieved from: https://economics.unian.ua/energetics/1098358-kabmin-zaklikav-radu-denonsuvati-ugodu-z-rf-schododobudovi-energoblokiv-haes.html.

5. Ukraine has increased electricity exports since the beginning of the year (2019), retrieved from: https://mind.ua/news/20204716-ukrayina-z-pochatku-roku-zbilshila-eksport-elektroenergiyi.

6. Ganna Lyuta (2019), Energy Bridge Ukraine - European Union: what could be its role in the European energy revolution? Retrieved from: https://dt.ua/energy_market/energomist-ukrayina-yevropeyskiy-soyuzyaku-rol-vin-mozhe-vidigra.

7. Cabinet of Ministers of Ukraine (2015), "On launching the pilot project "Energy Bridge" Ukraine European Union", retrieved from: https://data.rada.gov.ua/laws/show/671-2015-\%D1\%80\#Text.

8. Great opportunities: what a future EU energy man will give to Ukraine (2017), retrieved from: http://umoloda.kiev.ua/number/3243/159/118150/.

9. Tkach, D.K. (2018), "Ways to improve the functioning of the domestic energy market in the conditions of entering foreign markets", Vcheni zapysky universytetu "KROK”, №3(51), pp. 27-33. Doi: https://doi.org/10.31732/2663-2209-2018-51-27-33.

10. China offers Ukraine to complete the №4 KhNPP unit using its HPR-1000 technology, (2017), retrieved from: https://ua.interfax.com.ua/news/economic/459701.html.

11. The official site of Ministry of Energy of Ukraine (2020), retrieved from: http://mpe.kmu.gov.ua/minugol/control/uk/publish/article?art_id=244956254. 